\title{
Methodology for the Selection of In-Seam Gas Drainage System for Intensive and Safe Coal Mining Synops
}

\author{
Evgeny Yutyaev ${ }^{1}$, Evgeny Mazanik ${ }^{1}$, Sergey Slastunov ${ }^{2}$, and Andrian Batugin ${ }^{2, *}$ \\ ${ }^{1}$ JSC SUEK-Kuzbass, 652507, Leninsk-Kuznetsky, Russia \\ ${ }^{2}$ National University of Science and Technology «MISiS», Mining Institute, 119049, Moscow, Russia
}

\begin{abstract}
The article reviews general principles of selecting efficient solutions of in-seam gas drainage and provides analytical foundation for selecting parameters of in-seam gas drainage with due account for estimated output of production face. The schemes of degassing preparation at the production facilities of Kuzbass are presented. Recommendations are provided on the selection of in-seam gas drainage methods at the production areas of Kirova Mine, JSC SUEK-Kuzbass.
\end{abstract}

\section{Introduction}

Ensuring risk free environment in coal mines is currently of vital importance $[1,2]$. Worldwide extensive research is being conducted on issues related to effective degassing of highly gassy coal seams [3-10]. The coal mining company JSC SUEK-Kuzbass is the industry leader in Russia and issues of effective in-seam gas drainage are of great importance to ensure profitable and safe mining.

\section{Approach to the selection of the degassing preparation method}

We believe that the methodological approach to the selection of the coal seam degassing preparation method should be based on the following key factors:

- the predicted rate of coal seam methane yield determined at the stage of experimental work when the main characteristics and condition of the coal-and-methane-bearing reservoir (in-seam pressure, permeability, sorption characteristics of the coal seam) are the assessed;

- time required for in-seam gas drainage;

- values of the "gas content threshold" at estimated face output.

The integrated system of coal seam degassing preparation normally includes principal technology and auxiliary technological schemes that have successfully passed approvement

\footnotetext{
*Corresponding author: as-bat@mail.ru
} 
in underground conditions. Both international [11-16] and domestic techniques can be used for adequate determination of fundamental properties and characteristics of a coal seam.

The evidence from practice shows that at the depths where mines are currently operating the real effectiveness of gas drainage is often at $10 \div 15 \%$, which this is not enough to remove the restrictions on the enhanced face output. Therefore, designing and implementing more efficient in-seam gas drainage technology is becoming the key task to ensure methane safety of mining operations and significantly raise per face performance.

\section{In-situ experiments}

In our opinion, methodological recommendations on the selection of viable technological schemes for the degassing preparation of coal seams for subsequent production should include the implementation of two main stages, which we shall demonstrate by example of extraction panels 24-58, 24-59 and 24-60, Kirova mine (Table 1).

Table 1. Methodological recommendations on the selection of in-seam gas drainage method for extraction panels 24-58, 24-59 and 24-60, Kirova mine.

\begin{tabular}{|c|c|c|c|c|c|}
\hline Phase 1 & \multicolumn{2}{|c|}{$\begin{array}{l}\text { Target coal production. } \\
\text { The presence and magnitude } \\
\text { of the "gas content threshold" }\end{array}$} & \multicolumn{2}{|c|}{$\begin{array}{l}\text { Predicted methane yield } \\
\text { from unrelieved coal seams } \\
\text { taking into account in-seam } \\
\text { pressure }\end{array}$} & $\begin{array}{l}\text { Time } \\
\text { required } \\
\text { for } \\
\text { degassing }\end{array}$ \\
\hline \multirow{5}{*}{ Phase 2} & \multicolumn{5}{|c|}{ Justification for general technological design of in-seam gas drainage } \\
\hline & \multicolumn{5}{|c|}{ Pre- drainage (front-end, advancing drainage) of coal seam } \\
\hline & \multicolumn{5}{|c|}{$\begin{array}{l}\text { The parameters of the holistic technological scheme are determined by the project } \\
\text { design taking into account the availability and characteristics of tectonically } \\
\text { relieved and tectonically unrelieved zones. }\end{array}$} \\
\hline & \multirow{2}{*}{$\begin{array}{l}\text { Collecting } \\
\text { baseline } \\
\text { information at } \\
\text { the stage of in- } \\
\text { seam gas- } \\
\text { dynamics } \\
\text { research (GDR) }\end{array}$} & Drilling-in & $\begin{array}{l}\text { Principal } \\
\text { (base case) } \\
\text { technology }\end{array}$ & $\begin{array}{l}\text { Auxiliary } \\
\text { technological } \\
\text { schemes }\end{array}$ & $\begin{array}{l}\text { Means of } \\
\text { in-seam gas } \\
\text { drainage } \\
\text { stimulation }\end{array}$ \\
\hline & & $\begin{array}{c}\text { Coal seam } \\
\text { pre- } \\
\text { drainage } \\
\text { wells } \\
\text { (PDW) }\end{array}$ & $\begin{array}{l}\text { Coal seam } \\
\text { pre- } \\
\text { drainage in } \\
\text { zones of } \\
\text { undergroun } \\
\text { d hydraulic } \\
\text { fracturing } \\
\text { (UHF) }\end{array}$ & $\begin{array}{l}\text { Underground } \\
\text { hydraulic } \\
\text { fracturing of } \\
\text { seam (UHF) }\end{array}$ & $\begin{array}{c}\text { Auto- } \\
\text { pneumatic } \\
\text { impact } \\
\text { techniques } \\
\text { (API) }\end{array}$ \\
\hline
\end{tabular}

Standard in-seam gas drainage undertaken through wells drilled from development workings is used as principal (base case) technology. Parameters of this method are provided in Gas Drainage Operations Manual (2012).

Experimental work has been carried out on testing and approving auto-pneumatic impact method to justify the recommendation to use this technique to boost gas drainage in the production area 24-55. The essence of this method is described in [17].

The technology of hydrodynamic impact with underground hydraulic fracturing (UHF) of the coal seam to be drained is an auxiliary degassing scheme and is protected by patent [18]. It was tested in panel 24-58 (12 wells UHF) [19-21], it facilitated 3 to 4-fold growth of methane yield from in-seam gas drainage wells drilled in the hydrofracture zones, which 
resulted in significant improvement in terms of gas content in the longwall and allowed to raise face output.

\section{Results of field experiments and further discussion}

The effectiveness of underground hydraulic fracturing technology was evaluated in the process of longwall mining in panel 24-58. Comparison of the averaged longwall performance parameters in the hydraulic fracturing zone and those in the control zone is shown in Table 2.

Table 2. Longwall performance parameters in the hydraulic fracturing zone UHF vs. parameters in control zone.

\begin{tabular}{|c|c|c|c|c|}
\hline Parameter & Unit & Control zone & Zone of UHF & $\Delta, \boldsymbol{\%}$ \\
\hline Relative gas content & $\mathrm{m}^{3} / \mathrm{t}$ & 1.14 & 0.80 & 30 \\
\hline $\begin{array}{c}\text { Technological stoppages due to } \\
\text { "gas content threshold" - per day }\end{array}$ & $\mathrm{min} / \mathrm{day}$ & 122.39 & 71.45 & 42 \\
\hline Absolute gas content & $\mathrm{m}^{3} / \mathrm{min}$ & 8.29 & 7.29 & 12 \\
\hline Daily production & $\mathrm{tt}$ & 10747.16 & 13037.07 & 21 \\
\hline
\end{tabular}

It can be seen that in the areas of production face where hydraulic fracturing was performed the average value of relative gas content dropped by $30 \%$, production increased on average by $21 \%$, and process stoppages associated with the "gas content threshold" decreased by $42 \%$.

Improved effectiveness of in-seam gas drainage in the areas where hydraulic fracturing was performed in panels 24-58, 24-59, 24-60 and 24-62 justified the launch of large-scale gas drainage program in panels 24-63 and 24-64. The plan for 2019-20 is to implement the technology of advance in-seam gas drainage through surface boreholes combined with hydraulic dissection of the Boldyrevsky coal seam.

One of the important factors in selecting the in-seam gas drainage technology is the value of the "gas content threshold" and the determination of the in-seam gas drainage effectiveness required. Nomogram to determine the required yield of mehtane by in-seam gas drainage as applied to the Boldyrevsky seam at Kirova mine is shown in Figure 1. It helps to make a reasonable choice of in-seam gas drainage system depending on the required face performance.

Analyzing the situation in the mines of JSC SUEK-Kuzbass, following observations could be made. The Kotinskaya, the Taldinskaya-Zapadnaya and the Kirova mines have the highest per face output. Two of these - the Kotinskaya and the Kirova mines - are of interest in terms of gas factor. Analysis of per face output restrictions due to gas factor for a number of extraction panels at the Kirova and the Kotinskaya mines shows that in-seam gas drainage with a design efficiency of 0.2 to 0.3 is required for the majority (up to $80 \%$ ) of production faces. In-seam gas drainage practice at the aforesaid extraction panels of the Kirova mine confirms that such efficiency, under favorable conditions, can be achieved using advanced methods of pre-drainage undertaken from development workings (in particular, the option of holistic gas drainage technology is shown in Table 1). 


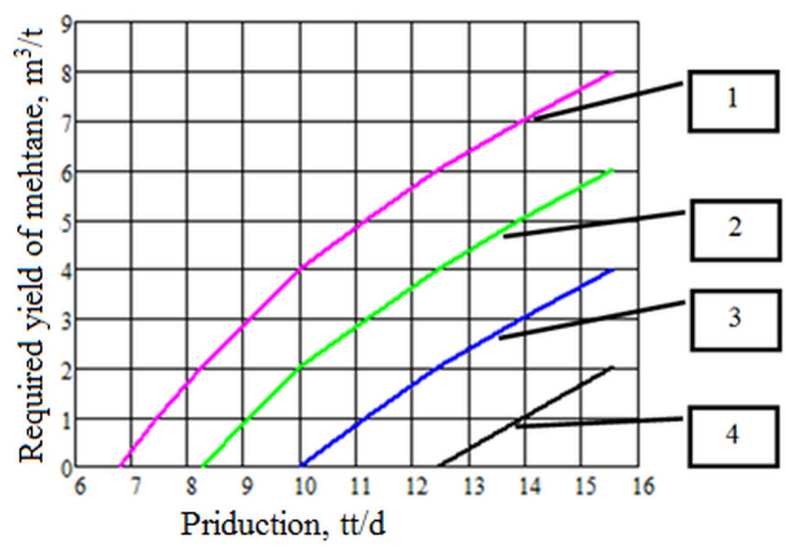

Fig. 1. Methane yield required to enhance face productivity. Baseline gas content of coal seam: 1) $18 \mathrm{~m}^{3} / \mathrm{t} ; 2$ ) - $16 \mathrm{~m}^{3} / \mathrm{t} ; 3$ ) $\left.-14 \mathrm{~m}^{3} / \mathrm{t} ; 4\right)-12 \mathrm{~m}^{3} / \mathrm{t}$.

The "Gas Drainage Operations Manual Instructions for Coal Mines", 2012, is the current regulations on gas drainage operations. The main parameters of in-seam gas drainage technologies are determined in accordance with this guideline document. In case reliable information about tectonically stress-relieved and tectonically stressed zones (TSRZ and TSZ) is available for particular mine areas, these parameters can be adjusted.

Gas drainage in the TSRZ zone is to some extent similar to gas drainage of coal seams relieved from ground pressure due to underworking or overworking of these seams. In TSRZ zones the parameters may be changed, i.e. hole spacing, i.e. distance between the holes, may be increased. The distance between the in-seam gas drainage holes at the Kirova mine can be increased, for example, from 12 to 18 meters, specifically in the areas of UHF, but this requires additional field trials, which is included in the program for further research.

The TSZ zone gas drainage is to some extent similar to gas drainage of coal seams unrelieved from ground pressure (either a single seam or the first seam in the series of strata). These coal seams have significantly lower permeability and can potentially be prone to outbursts. These parts of coal seams require mandatory use of complex in-seam gas drainage, including both basic (main) technologies and auxiliary active operations aimed at enhancing intrinsic gas permeability. Hydraulic fracturing of coal seams, for example, can be used as auxiliary seam treatment. In such cases, it is advisable to increase the volume of water injected, since moistening of coal seams increases their quasiplasticity and therefore reduces the outburst hazard. When hydrofracturing technology or, especially, hydraulic dissection is used, it is advisable to apply propant agent to fix gas draining cracks which can be more intensively closing in the TSZ areas. Specific recommendations should be based on the quantitative characteristics of the TSZ and TSRZ and specific properties (primarily gas permeability) and characteristics of the gas-related condition of the coal seam in these zones.

\section{Conclusions}

1. In-seam gas drainage technologies were studied in-situ whereby hydraulic fracturing and autopneumatic impact techniques were tested at the Kirov Mine production areas. Appraisal was made of their effectiveness and prospects for their further use as supplemental and boosting techniques as part of holistic in-seam gas drainage program. 
2. On the basis of the conducted studies, a methodological approach has been developed for the selection of viable gas drainage solutions to prepare coal seams for risk free mining. Following main factors should be taken into account when principal technological solutions are being selected:

- anticipated gas yield rate of coal seams, estimated at the stage of experimental (in-situ and laboratory) work based on reservoir pressure, coal seam permeability and its sorption characteristics (parameter factor),

- gas drainage time lapse (time factor),

- gas drainage depth required ("gas content threshold" factor).

3. On the basis of this approach, the selected parameters of in-seam gas drainage are justified with due account for estimated face output and recommendations are provided on the use of in-seam gas drainage technologies in the areas of the TSRZ and TSZ.

\section{References}

1. C. O. Karacan, F.A. Ruiz, M. Cote, S. Phipps, Int. J. of Coal Geol., 86, 23 (2011)

2. C. Hu, D. Wu, Quart. J. Ind. Pulp Paper Tech. Assoc., 30, 7, (2018)

3. L. Zhang, H. Zhang, H. Guo, Int. J. Min. Sci. Tech., 27, 4, (2017)

4. Z. M. Zhao, G. Wang, Ap. Mech. Mater., 580:583, 2558-2563 (2014)

5. W. Szott, M. Słota-Valim, A. Gołąbek, K. Sowiżdżał, P. Łętkowski, Int. J. Rock Mech. Min. Sci., 108, 1016 (2018)

6. M. V. Kurlenya, S. V. Serdyukov, T. V. Shilova, A. V. Patutin, J. Min. Sci., 50, 5 (2015)

7. P. Chareonsuppanimit, S. A. Mohammad, R. L. Robinson, K. A. M. Gasem, Int. J. Coal Geol., 121, 122 (2014)

8. K. Labus, R. Morga, T. Suponik, M. Masłowski, K. Wilk, P. Kasza, IOP Conf. Ser.: Earth Envir. Sci., 261, 012026 (2019)

9. V. Klishin, G. Opruk, A. Tatsienko, E3S Web Conf., 41, 03005 (2018)

10. D. W. Hine, K. Clarke, A. D. G. Marks, M.I. Morgan, Risk Analysis, 39, 3, (2019)

11. B. Nie, X. Liu, S. Yuan, et al. Adsorption, 22, 315 (2016)

12. L. Yang, Math. Prob. Eng., 73:5, 531 (2014)

14. H. J. Guo, Y.P. Cheng, L. Wang, S.Q. Lu, K. Jin, J. Nat. Gas Sci. Eng., 24, 45 (2015)

15. Q. P. Campbell, M. D. Barnardo, J. R. Bunt, J. of the South. Afric. Inst. Min. Metal., 113, $11(2013)$

16. H. Kang, X. Zhang, L. Si, Y. Wu, F. Gao, Eng. Geol., 116, 99 (2010)

17. S. V. Slastunov, G. G. Karkashadze, E. P. Yutyaev, E. V. Mazanik, Gornyi Zhurnal, 10, (2016) DOI: 10.17580/gzh.2018.01.15

18. S. V. Slastunov, G. G. Karkashadze, K. S. Kolikov, E. P. Yutyaev, E.V. Mazanik, A.P. Sadov, A.V. Ponizov, S.G. Nikitin, Russian Federation Patent, 2659298 (2016)

19. S. V. Slastunov, E. P. Yutyaev, Zapiski Gornogo Instituta, 223, (2017)DOI :10.18454/PMI.2017.1.130

20. S. V. Slastunov, E.P. Yutyaev, E.V. Mazanik, G.P. Ermak, Gornyi Zhurnal, 1, doi:10.17580/gzh.2018.01.15 (2018)

21. S. V. Slastunov, E.V. Mazanik, A.A. Meshkov, I.A. Komissarov, Min. Inform. Anal. Bull., 10, 110 (2018) DOI:10.25018/0236-1493-2018-10-0-110-117 